\title{
The Platonist Christianity of Marius Victorinus
}

\author{
Stephen A. Cooper
}

Department of Religious Studies, Franklin \& Marshall College, Lancaster, PA 17604-3003, USA;

stephen.cooper@fandm.edu

Academic Editor: Warren Smith

Received: 18 August 2016; Accepted: 20 September 2016; Published: 1 October 2016

\begin{abstract}
Marius Victorinus is the first representative of Platonist Christianity in the Latin church whose works display knowledge of Plotinus and Porphyry. Scholarship prior to the work of Pierre Hadot in the mid-twentieth century tended to treat him as an isolated figure, ignored by later Latin Christians who knew better how to moderate their Platonist borrowings. Scholars since then have been more willing to see Victorinus as earnest Christian who let himself be guided by the community standards of the church as laid out in the biblical canon and creedal definitions. Recent work on Victorinus' sources has shown him to be more eclectic in his use of philosophical sources than previously thought and for that reason more creative in formulating his Platonist-Christian synthesis. After reviewing important lines of development in scholarship on Victorinus, this article focuses on his Platonist-inspired teaching about the soul as expressed in the three genres of his Christian works: theological treatises, hymns, and scriptural commentaries. The consistent "insider" stance of Victorinus in all of these different genres of theological writings suggests that the extremely Platonist character of his theology, when considered in light of other early Christian thinkers, is a difference of degree and not kind.
\end{abstract}

Keywords: Neoplatonism; fourth-century church; Arian Controversy; Trinity; commentary on Paulconversion

\section{Introduction}

"Philosophers and those learned in the Law have made inquiries into Being and the Logos."

-Marius Victorinus, Adversus Arium IV $18 .{ }^{1}$

In a period when it was unexceptional for Christian authors to interpret the central tenets of their religion with Greek philosophical thought and terminology, Gaius Marius Victorinus (born in the $280 \mathrm{~s})^{2}$ stands as an exceptional figure in the fourth-century Latin church in the level of philosophical discourse he brought to the doctrinal problems of his newly adopted religion. ${ }^{3}$ Prior to becoming a Christian in the mid-350s, Victorinus was a celebrated professor of rhetoric at Rome and author of school-works of grammar, rhetoric, and dialectic. He also translated important Greek works, most significantly the "books of the Platonists" (Conf. 7. ix. 13) that deeply impacted Augustine. After his conversion, Victorinus entered the fray of the fourth-century trinitarian conflict by composing dense theological treatises and hymns, texts bristling with formidable Platonist vocabulary and thought. ${ }^{4}$ The series of commentaries Victorinus composed on the Pauline epistles also reveal his philosophical

\footnotetext{
All translations are my own unless otherwise noted.

For the probable date of his birth, see A. H. Harris [1].

The comprehensive treatment of Victorinus in Pierre Hadot's monograph [2] is indispensable.

The critical edition for the Vienna corpus [3] has been translated by the late Mary Clark [4]. For more recent bibliography on this works, see the edition and Italian translation of Claudo Moreschini and Chiara Ombretta Tommasi with its superb introduction [5].
} 
predilections in digressions on the realities of God and the soul intimated by the apostle. ${ }^{5}$ These works make Marius Victorinus the premiere Latin exemplar of the "remarkable synthesis" of Christianity and Platonism — thus Pierre Courcelle ([10], p. 253)—that came to fruition in Augustine and Boethius. ${ }^{6}$

In what sense this synthesis came to fruition in Augustine, and the role of Victorinus in transmitting it, have been perennial questions. Charles Gore, in a lengthy entry for the Victorian-era Dictionary of Christian Biography gladly granted Victorinus "the credit of a pioneer in claiming for Christianity the products of philosophy" and posited that the influence of his works "was a determining force upon the theology of St. Augustine" ([12], pp. 1137-38). Harnack lauded Gore's judgment and agreed: "unless all signs deceive, Augustine received from Victorinus the impulse which led him to assimilate Paul's type of religious thought" ([13], p. 34). Harnack went so far as to call Victorinus an "Augustine before Augustine" because of the sola-fideist expressions in his commentaries on Paul ([13], p. 35). This judgment, however, was soon rejected by the dissertations of Gustav Koffmane [14] and Reinhold Schmid [15]. ${ }^{7}$ Their negative conclusion was confirmed in the mid-20th century by the study of L. J. van der Lof [16], but at the same time Paolo Frassinetti detected similarities between Victorinus' Hymns and Augustine's Confessions [17]. Since the article of Pierre Hadot on this topic [18], more scholars have been found evidence of the influence of Victorinus upon Augustine through his trinitarian treatises $[19,20]$ and likely his commentaries on Paul as well. ${ }^{8}$ Nello Cipriani has been indefatigable in presenting numerous textual parallels between their works [22-25]. Recently Sarah Wear has concluded that in his discussions of John 5:19, "Augustine's use of esse and potentia has been heavily influenced by Marius' Trinitarian vocabulary, which is clearly rooted in Porphyry's discussion of the One" ([26], p. 117).

The most dramatic turns in scholarship of the last century have been the discovery of philosophical sources in Victorinus' trinitarian treatises. This has made the exact nature of the Platonist part of his thought difficult to evaluate in its historical dimension, since some sources are of unclear origin. The generally Neoplatonist character of the thought in Victorinus has long been recognized, and Plotinus was held to be his main philosophical source. ${ }^{9}$ Yet no verbatim use of Plotinus had been detected in Victorinus' work until Paul Henry found an unmarked quotation of the opening sentence of Enneads V 2 in one of Victorinus' trinitarian treatises ([28], p. 49). ${ }^{10}$ In his work toward the critical text of Plotinus, Henry engaged Pierre Hadot to scour Victorinus' treatises for more Plotinus, but what Hadot found demanded a re-evaluation of the kind of Platonism informing Victorinus' idiosyncratic trinitarian theology. Hadot's 1968 Porphyre et Victorinus demonstrated how Victorinus likely made extensive use of an anonymous Greek commentary on Plato's Parmenides, which the French scholar attributed to Porphyry ([27], pp. 102-43). Hadot had noted certain philosophical passages with distinct vocabulary that marked them as three distinct sets of "literary unities". ${ }^{11}$ Although these passages are not quotations of any known work by Porphyry, Hadot identified their combination of vocabulary and conceptuality as Porphyrian, in part on the basis of similarities between the anonymous commentary on the Parmenides and the material in Synesius' Hymns that Willy Theiler in 1942 had argued depended

5 Franco Gori has edited the critical edition for the Vienna Corpus [6]. I have translated Victorinus' commentaries, with introductions and notes, on Galatians [7] and Ephesians [8]. For a brief survey of his life, works, and thought, see my contribution in the Cambridge History of Philosophy edited by Lloyd Gerson [9].

6 For the relation between Victorinus and Boethius, see Hadot ([2], pp. 20, 367-69), Moreschini [11], and John Magee in ([9], pp. 791-93).

7 Harnack retreated somewhat in a later edition of the Dogmengeschichte: "The name of Victorinus is not the important point for the history of dogma, but the indisputable fact that the combination of Neoplatonism and orthodox Christianity existed in the West, in Rome before Augustine under the badge of Paulinism" ([13], p. 37).

8 See ch. 2 of Eric Plumer's translation of Augustine's Commentary on Galatians [21], as well as my own analysis ([7], chapter 6).

9 See, e.g., the work of Gore [11] as well as Hadot's full account of the scholarly discussion in his ground-breaking Porphyrius et Victorinus ([27], pp. 19-29).

10 An introductory gloss by Victorinus makes God the subject instead of the One: "Some have said that God as 'the One is all things and not one of them, for he is the principle of all'-whence he is not all things-'but he is all things in that mode,' he says" (Adv. Ar. IV 22; [3], p. 258). See Henry's presentations ([28], p. 49) and [29].

11 These passages are printed as vol. 2 of Porphyrius et Victorinus ([27], vol. 2, pp. 13-55). 
on Porphyry's lost commentary on the Chaldean Oracles [30]. Hadot's ascription of the fragments of the commentary on Parmenides to Porphyry received much support, e.g., from H. D. Saffrey [31], John Dillon [32], Ruth Majercik ([33], p. 2660), and Marco Zambon ([34], p. 40). Alessandro Linguiti, in his edition of these fragments [35], has provided a status quaestionis and opts for a post-Porphyrian author, as has Matthias Baltes ([36], pp. 115-23), and Andrew Smith, the recent editor of the Teubner edition of Porphyry [37].

The debate has become more heated with claims for pre-Plotinian authorship been mounted by Gerald Bechtle [38] and Kevin Corrigan [39]. Majercik has lodged weighty objections to this [40], but scholarly opinion remains divided. The critics who prefer a Middle Platonic provenance for the anonymous commentary have been successful at least in demonstrating that even prior to Plotinus there was an intellectual milieu in which these theological reflections on the Parmenides could have plausibly taken place. ${ }^{12}$ This erodes the validity of "Neoplatonism" as a category of historical analysis, which is one of the reasons why Lloyd Gerson in the recent Cambridge History of Philosophy in Late Antiquity has argued for eliminating the term as "an artefact of eighteen-century German scholarship" ([9], p. 3).

More recent questions and uncertainties about Victorinus' sources arose with the startling discovery published by Hadot [43] and Michel Tardieu in 1996 [44]. ${ }^{13}$ The two scholars detected parallel material in Victorinus' Adversus Arius IB (49-50) and in the Coptic gnostic work Zostrianus (NHC VIII, 1). ${ }^{14}$ The parallels are so substantial as to require some literary relationship between them. Based on the clarity of the order of exposition in Victorinus and the "patchwork" quality of some of the corresponding material in Zostrianus, Tardieu argues that both drew from a common Middle Platonist source, perhaps Numenius ([44], pp. 112-13). The presence of "Spirit" in the unknown source as a name for the highest divinity is a problem, insofar as this theological nomenclature was at home among Christians, gnostics, and Stoics but foreign to Platonists, insofar as pneuma meant a material substance and therefore was unacceptable nomenclature for an immaterial divinity. Tardieu thinks it possible the term drifted into the Middle Platonist author from the Middle Stoic theological use of pneuma as equivalent to the material, causative "fire" of the cosmos ([44], pp. 62, 90-95). Hadot granted Tardieu's basic claim of an originally Middle Platonic document, but he accounts for the use of "Spirit" by maintaining that this philosophical text had been redacted by a Christian or gnostic author who utilized the source to defend the Nicene homoousion ([43], pp. 124-25).

Scholars have largely concurred with the conclusion that a new source for Victorinus' thought had thus been discovered, with exception of Bechtle ([46], p. 568), ${ }_{1}^{15}$ who identifies the material in Adv $A r$ IB $49-50$ as belonging to the anonymous commentary on Parmenides. Yet the use of a common source by the author of Zostrianus and Victorinus is not the only possible way to explain the parallels. Chiara Tommasi has argued in a series of articles [47-50], the first of which appeared in 1996, for a different explanation of the parallels between Victorinus and Nag Hammadi texts such as had been previously been noted by Antonio Orbe [51 $]^{16}$ and Einar Thomassen ([52], p. 370). Tommasi argues that a direct reading of gnostic texts by Victorinus explains the data more simply and removes the problem Tardieu and Hadot saw in the presence of "Spirit" in the putative Middle Platonist common

12 See the collection edited by John D. Turner and Kevin Corrigan Plato's Parmenides and its Heritage [41]. For an excellent synopsis and critical discussion of Hadot's claims about Porphyry, see Volker Henning Drecoll's article in this collection [42].

13 The discovery happened when Tardieu noted in Zostrianus (NHC VIII, 1) the technical formula "logos of himself" (Zostr. 66,

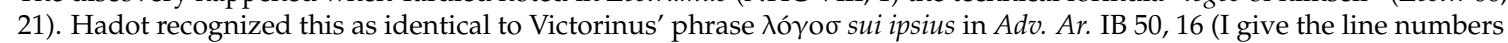
of CSEL edition of Victorinus). Both phrases also contain in tandem with logos the term idea, albeit in different order in each text.

14 For this text, see the critical edition (with introductions, translation, and commentary) in the series Bibliothèque Copte de Nag Hammadi [45].

15 Bechtle proposes to cut the Gordian knot by identifying the source behind the parallels between Zostrianos and Victorinus with the Anon. in Parm. Tardieu acknowledges point of contact between Anon. in Parm. IX, 4 and the shared material in Zostr. and Victornus but holds the latter is dependent on the former ([44], p. 100).

16 Orbe's work did not escape the notice of Hadot; see the status quaestionis by Tardieu ([44], pp. 10-15). Tardieu lists eight "principal developments and themes common to Adversus Arium and gnostics" that Hadot noted in the Sources chrétiennes edition (vols. 68-69) of Victorinus' treatise. 
source. Why would Victorinus not have read gnostic texts, or perhaps refutations of Platonizing gnostic texts like Zostrianus? Porphyry mentions Zostrianus as one of the several "revelations" produced by gnostics who frequented Plotinus' lectures, and that Plotinus' student Amelius refuted it wrote forty books (Vita Plot. 16). Augustine states that Victorinus before his conversion was studying "all Christian writings," 17 and there is no assurance he read only orthodox ones. On the other hand, if the parallels are better accounted for by supposing Zostrianus and Victorinus drew on a common pre-Plotinian source, then his trinitarian theology, as John Turner argues, "had its metaphysical basis, not exclusively in Porphyry or later Neoplatonists, but also in the pre-Plotinian/Middle Platonic philosophy of the sort best preserved in the Platonizing Sethian treatises from Nag Hammadi" ([53], p. 85). ${ }^{18}$

A comprehensive review of all these lines of scholarship and further valuable recent contributions ${ }^{19}$ treating the philosophical aspects of Victorinus' work would require a lengthy monograph. Here, I undertake a more modest endeavor of surveying the three genres of Victorinus' Christian literary corpus - treatises, hymns, and commentaries-for elements of Platonist thought that figure importantly in his Christianity. It is generally acknowledged that the impact of philosophical thought in Victorinus' Christian works makes itself particularly felt on the one hand in a doctrinal and anti-heretical thrust-this is his doctrine of God-and then on the other hand in his soteriology, chiefly his teachings on the soul. ${ }^{20}$ It is these two areas that I will examine. As Victorinus is not among the better known of early Christian author, I first present basic biographical data relevant to his profile as a Christian Platonist. Next will follow a survey of his trinitarian treatises to observe notable features of his polemical and constructive philosophical theology. A brief third section will bring his Hymns into to view as particularly revealing of his Platonist-Christian piety. A fourth section will focus on his teaching on the soul and how the Platonist ontology works to articulate his Christian understanding of salvation. In conclusion, I will reflect on what Victorinus can tell us about "Platonist Christianity" and what it was to him. ${ }^{21}$

\section{Platonism in Victorinus' Life and Work}

Born in Roman Africa, Victorinus rose to the top of his profession in Rome as professor of rhetoric. He composed a number of works for instruction in grammar, rhetoric, and dialectic, some of which continued to be used the Middle Ages, especially his Commentary on Cicero's On Invention, ${ }^{22}$ which became a standard reference text. ${ }^{23}$ Holding the public chair of rhetoric for the city of Rome under Constantius, Victorinus eventually received the honor of a statue in Trajan's Forum in 354-as Jerome relates (Chronicon 2370) - and became vir clarissimus, i.e., was elevated to the senatorial order. Not long after the award of the statue Victorinus converted to Christianity, in 355 or 356, "at an advanced old age" (Jerome, De vir. ill. 101). By 357 he began writing his trinitarian works. Augustine provides the interesting biographical notice (Conf. 8. v. 10) that Victorinus resigned his chair of rhetoric when emperor Julian urged extreme vetting to ban from municipal teaching positions on 17 June 362 (Cod.

17 My translation of Conf. 8. ii. 4: legebat, sicut ait Simplicianus, sanctam scripturam, omnesque Christianas litteras investigabat studiosissime et perscrutabatur.

18 See also Turner's more recent attempt to grapple with the problem [54], where he provides a useful table of the parallel passages in synoptic columns ([44], pp. 166-71).

19 Chiefly to be noted is the 2012 issue of Les Études philosophiques in memory of Pierre Hadot [55]. This volume features a sheaf of penetrating articles exploring the elements of Victorinus' theology which highlight his use of scripture and philosophical sources (Aristotle, Plotinus) but also the impact of his work on Augustine and Boethius. Other significant recent contributions on philosophical aspects of Victorinus' thought are the articles of Serge Cazelais [56], Alexey Fokin [57,58], Václav Němec [59,60], Lenka Karfíková [61], Anca Vasiliu [62,63], and that of Sarah Wear [26]. Reference to earlier scholarship on the topic can be found in my previous publications $[8,64,65]$.

20 I have previously discussed Victorinus' soteriology in regards his Pauline exegesis ([7], pp. 127-70) and in relation to his conversion ([8], pp. 15-22, 24-29).

21 For excellent discussion — and vindication—of scholarly use (and criticism) of this analytical construct, see the recent contributions of C. J. De Vogel [66] and Claudio Moreschini [67].

22 Citations will be of the critical edition of Halm, Rhetores Latinae Minores [68].

23 See the articles of John Ward [69] and Guadalupe Lopetegui Semperena [70]. 
Theod. 13. 3. 5; Julian, Ep. 36). By 363, Victorinus completed the last of his treatises and began a series of commentaries on the Pauline letters that extended at least to Philippians ([7], p. 4).

Victorinus' professional writings, composed before his conversion, are recommended by Cassiodorus (Instit. II 10, 14; III 13, 18) and furnish us with a partial intellectual profile of the rhetor. In his Commentary on Cicero's Rhetoric, Victorinus enriches his presentation of rhetorical theory and practice with treatments of philosophical themes and terms in Cicero's text to explain elements of Aristotelian logic, dialectic, or general Platonist doctrines. ${ }^{24}$ His references to Plato there consist of handbook-level Platonist doctrine ([2], p. 79), ${ }^{25}$ but this does not necessarily reflect Victorinus' full knowledge of Platonism at the time. The graded approach of the late antique curriculum meant philosophy was a sphere of study beyond the standard course of grammar and rhetoric, in which Victorinus liked to include elements of logic. "Philosophy in its complete form," clarifies Victorinus in his commentary on Cicero, "consists of two elements: physics and ethics. Physics is the part which treats of divine realities [divina], and ethics the part which discusses things human" (In Cic. Rhet. I. 2; [68], p. 160). He thus rejected of the common Old Academy (Platonic) and Stoic tripartite classification that included logic in philosophy in favor of the two-fold, Aristotelian division where logic was regarded logic as preparatory [73]. Victorinus' translation of Porphyry's Introduction to Aristotle's Categories (fragments are preserved in Boethius's first commentary on the Isagogê) suggests he followed the Neoplatonist reception of Aristotle. The brief but original treatise On Definition shows Victorinus' interest in logic, as does his lost work On Hypothetical Syllogisms, incorporated in part by Martianus Capella and Cassiodorus in their own works (the latter also preserved passages of Victorinus's four-book commentary on Cicero's Topics). ${ }^{26}$

Thus, it is only due to Augustine's account of Victorinus as the translator of the libri Platonicorum that we know him to have been familiar with Neoplatonist philosophy prior to becoming a Christian. These works included some of Plotinus' Enneads and at least one work by Porphyry ([74], p. 7), likely the De regressu animae quoted by Augustine in book ten of City of God. ${ }^{27}$ It not far fetched to imagine the instructor of "so many noble senators" (Augustine, Conf. 8. ii. 3) would have a ready audience for his translations among those who, like Augustine, had philosophical interests but lacked the Greek to keep abreast of developments in Platonist thought.

We are also dependent upon the Confessions for information about Victorinus' conversion. This account describes him as having repeatedly claimed to his friend Simplician that he was a Christian. Simplician, a younger man (and perhaps a former student of Victorinus), kept saying to him in return, "I shall not believe that or count you among the Christians until I see you in the Church of Christ." His response, as Augustine gives it, was a serious jest: "Victorinus laughed and said 'Then do walls make Christians?'” (Conf. 8. ii. 4). ${ }^{28}$ The remark about the walls, as Courcelle pointed out [77], is a Stoic commonplace for signaling the soul as the site of true religion. In what follows, Augustine says that Victorinus hesitated to enter the church because he was "afraid to offend his friends, "proud devil-worshippers" - clearly, the largely pagan aristocratic circles of Rome who would have been important sources of patronage for the working rhetor.

Hadot has been skeptical about Augustine's account of Victorinus' motives for hesitation and has reconstructed a different picture of the pre-Christian Victorinus. On the basis of passages in the commentary on Cicero, Hadot ([2], pp. 47-52) argues that Victorinus adhered to an aspect of Porphyry's thought that conceived human discourse about the divine as a matter of opinion and conjecture. ${ }^{29}$

24 Most of these passages are translated and discussed by Stephen Gersh ([71], vol. 2: 719-27). Cf. also Hadot ([2], pp. 79-101) and Karlhermann Bergner [72].

25 Hadot ([27], p. 84, n. 4) also noted the similarity of this material with the Porphyrean teaching on the soul in Firmicus Maternus (Math I, 4).

26 Hadot has reprinted what remains of these works as appendices [2].

27 These quotations have been printed as fragments 283-302 by Andrew Smith in his Teubner edition of Porphyry [75].

28 Translation by Henry Chadwick ([76], p. 136).

29 See the recent discussion of skepticism in Victorinus and Augustine by Anne-Isabelle Bouton-Toubloulic [78]. 
He also questions Augustine's claim that before his conversion Victorinus had defended the pagan gods "with a voice terrifying to opponents" (Conf. 8. ii. 3). ${ }^{30}$ Augustine, Hadot suggests, retrojected the hostility between Christians and pagans during his time Italy to the situation of Victorinus three decades earlier. Yet the Confessions was written when Simplician was still alive; Augustine will hardly have misrepresented the latter's report. Thus, I am not inclined to think the jibe about the walls making Christians came from a flourish of Augustine's pen. Victorinus with his fluency in Greek and great knowledge of philosophy knew Stoicism well enough to fashion the bon mot himself. ${ }^{31}$

What made Victorinus convert, Augustine's account suggests, is that the old professor came to believe that knowing the truth of the church's doctrine was not enough to ensure he was counted as a Christian at the hour of reckoning. Taking the issue of the afterlife seriously does not diminish other possible concerns on Victorinus' part. I have elsewhere maintained ([8], pp. 24-29) that the desire to bring his private profession into public light (Conf. 8. ii. 5) coheres fully with the portrait of Cicero's orator drawn by Victorinus his commentary on De Inventione (see Section 5 below).

\section{Platonist Thought in Victorinus' Trinitarian Treatises}

At a time when the emperor Constantius had made it clear he never wanted to hear the word homoousios again, Victorinus became a vociferous partisan of the Nicene Creed. Henry Chadwick has noted that " $\mathrm{t}$ ] he timing of his conversion was close to the drama of Liberius' exile and the western realization that in the demand for a condemnation of Athanasius the underlying issue was the truth or falsity of 'Arianism'"' ([81], 280). In the years leading up to Victorinus' conversion (circa 355), pope Liberius had been intransigent in his support for Nicene creed and for Athanasius, whom he refused to condemn in spite of heavy pressure from Constantius. The emperor had him arrested under cover of night (Ammianus 15. 7. 7-10) and Liberius was exiled to Thrace, where he remained for almost three years (356-358) until he capitulated and was returned to Rome to resume his office. ${ }^{32}$

Victorinus' treatises reflect this situation in various ways. The first four of his nine treatises are presented as an epistolary exchange between Victorinus and an "Arian" named Candidus, whom scholars agree is a purely literary persona ([2], pp. 272-75). The opening arguments of "Letter of the Arian Candidus to the rhetor Marius Victorinus about the divine begetting" furnish standard Platonist fare. The premise that all generation involves change (mutatio) leads to the conclusion that there can be no generation in God, because everything divine (divinum) is "unchangeable" (inmutabile). What is divine "is neither begotten nor begets anything....and so God is unbegotten" (Cand. I. 1; [3], p. 1). After a long discussion of the various ways one might think of there being generatio from God (Cand. I. 4-9), Candidus conclude that the logos, the Son of God, existing "not by a begetting from God but by a working [operatione] from God, is the first and principal work [opus] of God" (Cand. I. 10; [3], p. 12). The implication is that Christ, the begotten Son, is not God in the proper sense. Candidus displays typical "Arian" piety by stating that no dishonor should accrue to Jesus in this view of him as "a work of God perfect in every respect, God by the power of God, Spirit above all spirits, the Only-begotten by that working [sc. of God], Son in power, made in a substance, not from a substance" (Cand. I. 11; [3], p. 13).

Victorinus' first response to Candidus (Ad Candidum) argues for a kind of "generation" in God that does not involve change. He addresses these problems by a complex Platonist ontology, an elaboration of the division between realities apprehended by the senses and those grasped by the mind apart from the senses. ${ }^{33}$ The opening this treatise lays out Victorinus' presuppositions about the knowledge of God and how the gap between the realm of the divine and that of embodied souls can be narrowed:

30 Translation by Chadwick ([76], p. 135).

31 On Stoic elements in Victorinus, see Hadot ([27], pp. 225-46), Andreas Pronay ([79] pp. 21-22), and Maria Corsini ([80], pp. 200-10).

32 For an account of these events, see Chadwick ([81], pp. 266-68, 280-86).

33 Much of this material is among the first group philosophical passages isolated by Hadot ([27], vol. 2, pp. 13-20). 
To speak about God is an act of daring beyond human capacity. But since the nous patrikos [paternal intellect] has been inserted into our soul, and since the Spirit sent from above sets in motion the figments of the intelligible realities inscribed from eternity in our soul, it is as if some transport of the soul's mind ${ }^{34}$ longs to see ineffable things and untraceable mysteries of the intentions and workings of God. With the soul now set in such a body, it is difficult alone to understand these things and impossible to relate them. ${ }^{35}$ (Ad Cand. 1; [3], p. 15).

Victorinus is clarifying the problem of the soul much as did Plotinus in On the Three Primary Hypostases (V 1). Elsewhere Plotinus wrote of the soul's lostness in the "region of unlikeness" (Enn. I 8.13), ${ }^{36}$ rendered by Victorinus as regio dissimilitudinis and slyly inserted by Augustine into Conf. 7. x. 16 [29]. It is noteworthy that this passage forms part of the proemium of Ad Candidum, where one would expect to find a statement of the problem to be resolved and some indication of the discussion to follow. ${ }^{37}$ While Victorinus in his commentary on Cicero gave only a basic sketch of the problem of the soul seeking its while in the body (discussed in $\S 5$ below), this passage from Ad Cand. 1 presents a more complex teaching. Victorinus appears to have incorporated into his Christian soteriology the idea of the nous patrikos from the Chaldean Oracles (probably through Porphyry's commentary on the same). Fragment 109 of the Oracles-a Middle Platonist work open to such revelations as the gods gifted to "barbarian" people-is particularly relevant: "But the Paternal Intellect does not receive the will (of the soul) until it emerges from forgetfulness and speaks a word, remembering the pure, paternal token." ${ }^{38}$ Victorinus invokes it to explain how the soul can move toward its origin despite the difficulties attending its embodied existence. Serge Cazelais has recently drawn attention to a particular phrase of this passage-quasi quaedam mentis elatio nostrae animae: "as if some transport of the mind of the soul longs" - as key to Victorinus' treatment of the topos from the Timaeus about the difficulty of knowing God, which is surmounted by the gift of the Spirit, the revelation of faith ([56], pp. 60-62). This opening of Ad Candidum shows Victorinus integrating philosophical thought with that of Christianity by coordinating the seed-sowing of the paternal intellect with the work of the Holy Spirit as activator of souls in stirring them toward the higher realities.

The treatise take a polemical turn in which Candidus receives an earnest brow-beating. Victorinus then attempts to get to the heart his objection concerning the immutability of God and the problems with speaking of a divine substance. Agreeing with Candidus that the Aristotelian notion of substance as subject to accidents cannot be applied to God, Victorinus argues that ousia language is legitimate in light of the philosophical use of the participle form of the Greek verb to be, to on, generally translated "Being" or "that which is" (e.g., Plato, Rep. 508B). "Being" in the interpretation of the Parmenides is the second One, the One that is also many, which is produced by the One (Parm. 137c-142a and 143a-144b). Victorinus can thus state that God is the "power of Being itself" (potentia ipsius tou ontou), which power "generated [genuit] Being complete in every respect [to on omnimodis perfectum], generated the entirety of Being from the entirety of the power." His argument depends on changing the meaning of potentia, from the meaning "potentiality" (which Candidus denied could be prior to God in Cand. 1.1) to that of an unlimited power-what Plotinus called "the productive power [dunamis] of all things" (V. 4. 2) ${ }^{39}$ - that give rises to the realm of Being. God the Father is accordingly to proon, "pre-Being" (Ad Cand. 2; [3], p. 18); and in this way there is no movement implying change, no "this

34 See below (Section 3) for discussion of this part of the soul, which he elsewhere call the "divine soul" that becomes incarnate in individuals.

35 This last clause is a paraphrase of Plato's famous dictum in Timaeus 28A: "But the father and maker of all this universe is past finding out; and even if we found him, to tell of him to all men would be impossible" (Jowett).

36 Translated by A. H. Armstrong ([82], vol. 1, p. 309).

37 Victorinus says of Cicero's opening to book II of De inventione: "Every preface is like an image [quasi similitudo] of what we are going to talk about" ([68], p. 257).

38 Translated by Ruth Majercik ([83], p. 91).

39 Translated by Armstrong ([82], vol. 5, p. 149). 
becoming that," insofar as God as pre-Being possesses no determinateness whatsoever so as to be a "this" at all.

Candidus' response to Victorinus (Cand. II) consists for the most part of Latin translations of important letters from the beginning of the trinitarian controversy. These "Arian" letters provide Victorinus the textual basis for his second refutation of Candidus in Adversus Arium I (Adv. Ar. IA). ${ }^{40}$ This his lengthiest treatise begins as an exegetical onslaught against those who oppose the Nicene definition of Christ as homoousios with the Father. In chapters 2-27, Victorinus surveys scriptural passages help him vindicate the Nicene language and theology. This orderly procedure, however, appears to have been interrupted by his reception of new information and documents pertinent to the platform of the moderates led by Basil of Ancyra in 358. He and his confederates had been alarmed by the vehemently anti-Nicene statement of a council at Sirmium in $357^{41}$ that attempted to ban the theological use of the term ousia. In response Basil sought to substitute homoiousion- "of similar substance"-for the controverted Nicene phrase "of the same substance." 42

Victorinus would have none of this. Breaking off his survey of scriptural texts he rips into Basil and his party for thinking it was coherent to maintain that the Son was of "similar substance" (homoiousion). ${ }^{43}$ Similarity of likeness refers to quality and is accordingly not a term that can be discussed in the category of substance; to say "of similar substance" is "impossible and incongruous," as similarity implies some "alterity" (Adv. Ar. 1A 23; [3], p. 93). Victorinus opposed both the radicals of Sirmium and the homoiousian party by arguing for a metaphysical use of the term substantia carefully distinguished from the materialistic sense of its standard use to talk about composite physical entities. This point, as scholars have observed, is a standard piece of the Neoplatonic interpretation of Aristotle's Categories. ${ }^{44}$

Victorinus's next work is a treatise entitled "That the Trinity is homoousios" (Adv. Ar. IB). This treatise, along with $A d v$. Ar. IV, is the source of most of the philosophical blocks of material assembled by Hadot. The work also contains the parallels to Zostrianus. Chapter 62 contains a passage of mixed exegetical and philosophical argumentation, which is important for understanding how Victorinus correlated his Platonist anthropology with the creation account in Genesis. ${ }^{45}$ He quotes Genesis 1:26 at the conclusion of a disquisition on the relation of soul-the hypostasis of soul-to Intellect and how soul descended from Intellect (nous), which it images. ${ }^{46}$ The soul "with its own nous ...is an intellectual power of life," but it descends from Intellect by its attention to lower realities which it gives life. "Cast in shadows, the soul is drawn below" (Adv. Ar. IB 61; [3], p. 162). Victorinus then offers a way to understand what Gen 1:26 means in light of the account of soul just given, and he mentions four views of the constituents of human nature. He identifies his own view as the final suggestion: human beings possess "a four-fold body of the four elements along with a double soul and double intellect [nous]." That God "took dust and formed Adam" (cf. Gen. 2:7) signifies the earth, including "the high point of earth and its flower," ${ }^{\prime 7}$ which together constitute "the principles of the body" (Adv. Ar. IB 62; [3], p. 163). This human endowment with a "double intellect and a double soul" is allegorically revealed in the gospel story of two men working in the field or two women grinding grain (Matt 24:39-41; Luke 17:34-3). Victorinus explains that there is "a heavenly nous or logos and a

40 The earliest modern editor, Johannes Sichardus (1528), regarded the fourth and fifth treatises as two books of a single work extending to the sixth, seventh, and eighth treatises, which he accordingly entitled Against Arius I-IV, probably in line with Jerome's remark (Vir. ill. 101) that Victorinus "wrote very obscure books against Arius" ([2], p. 255).

41 The so-called 'Blasphemy of Sirmium.' Original text in Hilary, De syn. 1: "about the term 'substance', which the Greeks call ousia, no mention should be made at all" (the Greek version is in Athanasius, De syn. 28).

42 See R. P. C. Hanson ([84], pp. 348-71, 531-56) and Mark Edwards [85] for accounts of Basil and Victorinus' response to him.

43 Adv. Ar. I 28, 32; 29, 35; 30, 4-5. See Hadot and Brenke ([86], pp. 58-59) for discussion of the documents assembled by Basil and his sympathizers at synod of Sirmium in the summer of 358.

44 For recent discussion, see Němec [60].

45 See Massimo Stefani's full analysis of this passage [87].

46 On the dual role of the "image" in Victornus, see Vasiliu [63].

47 These terms from the Chaldean Oracles (see fragments. 1, 37, 76 in [83]). 
heavenly soul, but also a material logos and material soul." These four nest within each other and all within the body:

As the power of sense-perception, the material nous is situated in and consubstantial with the material soul. This being so, the heavenly logos—meaning nous or divine spirit-is in the divine soul. But this divine soul is in a material spirit, and the material spirit [hylicus spiritus] in a material soul, the material soul in a fleshly body, which it must be purified with all three for the person to receive eternal light and eternal life. And this is what faith in Christ brings about. (Adv. Ar. IB 62; [3], 164).

Since a "divine spirit" resides in this "divine soul" ${ }^{48}$ which is in turn enveloped in the "material spirit" - the ochêma or "pneumatic vehicle" in Platonist language ${ }^{49}$ — that enables a spiritual reality to be located in a material body. The divine soul is the representative of the higher realm as a descendent of the world-soul, which Victorinus as a Christian theologian put outside the divine proper.

Victorinus' sixth treatise, "On the homoousios in both Greek and Latin against the heretics" dates to the period between the Council of Ariminum in 359 and the death of Constantius on Nov. 3, 361 (Adv. Ar. II 9; [3], p. 183). Here Victorinus anticipates philosophical concern about the Nicene terminology on the part of those who might object that speaking of God as ousia violates the negative theology emerging from commentary on the first hypothesis of the Parmenides, which insisted on the transcendence of the One above all categories. To those who would prefer to say that God's existence is therefore "nonsubstantial" (anousios), Victorinus counters that one can take "substance" as synonymous with existence more generally and accept talk of the "substance" of the transcendent God to signify the existence of the divinity. Of particular note in his treatise is Victorinus' much discussed usage of the Latin infinitive esse to approximate the Greek articular infinitive of the verb to be (to einai) [88], which is extensively employed in the anonymous commentary on the Parmenides. ${ }^{50}$ "To Be [esse] is for God his own substance," declares Victorinus. "God, bestowing To Be from himself to himself, is the primary substance, universal substance, substance before substance." Victorinus observes that "certain people" are willing to use this term to indicate that God is huperousios, "transcendent substance" (Adv. Ar. II 1; [3], p. 169), which would seem to be his own perspective as well. The ninth treatise, "On the necessity of accepting homoousios" (De hom. rec.), is almost an abbreviation of Adv. Ar. II in presenting scriptural and philological arguments for the applicability of the term.

The seventh (Adv. Ar. III) and eighth treatises (Adv. Ar. IV), both entitled "On Homoousios," were likely written shortly after the sixth treatise, in 360-362. They contain a number of points of great interest. Adversus Arium III features an elucidation of the logos as the image of God and the soul as the image of that image. Hadot has argued from this and similar passages that Victorinus anticipated Augustine's psychological analogy for the Trinity [18]. ${ }^{51}$ The eighth treatise, likewise entitled "On Homoousios" (Adv. Ar. IV) is another attempt to explain Victorinus' account of the trinity, which involves the mutual implication of the persons of the Trinity, especially the dyad of Christ and Holy Spirit. Granting the obscurity of his discussion owing to "the repetition of terms" (Adv. Ar. IV 3; [3], p. 228), Victorinus emphasizes as a starting point the conviction that "God exists" and that in accord with the scriptures, God's "To be" (esse) must be called Spirit. "What do we believe in regard to this [divine] esse, what do we maintain about it?" "God is spirit," he says quoting John 4:24, "God is light and the true light" (Adv. Ar. IV 4; [3], p. 228). The treatise continues with a breath-taking range of philosophical vocabulary and conceptuality-certainly the most audacious attempt at philosophical theology in the early Latin church.

48 Victorinus refers to soul as "divine" without thinking it God, just as in modern parlance one can acknowledge a spiritual aspect to human beings without identifying them with God.

49 On this concept in Platonism, see Dillon's account ([9], p. 366).

50 For discussion of how this works out in Platonist Christian authors, see Girgenti [20].

51 Hadot's point was anticipated by Ian Hoslip [89] 


\section{Platonism in Victorinus' Hymns}

Victorinus' three hymns are not constructed according to the metrics of classical poetry but reflect a developing Christian form of accentuated strophes ([90], p. 72). The dense philosophical content and vocabulary of the first hymn, although leavened by language of the fourth gospel, overwhelms any aesthetic or hymnic qualities it otherwise possesses. The opening at least breathes the spirit of the author's piety:

Be there [Adesto], true light, Father and Almighty God!

Be there, true light, mystery and power of God!

Be there, Holy Spirit, bond of the Father and the Son!

When you are still, you are the Father; when you go forth, you are the Son.

You who join all things in one, you are the Holy Spirit.

(Hymn I; [3], p. 284).

"Mystery" and "power of God" are of course Pauline expressions; "true light" is from John 1:19. That the Spirit is "the bond" [copula] of the Father and the Son-or the connexio of them ${ }^{52}$-is a note that scholars have long suspected Augustine to have absorbed and tweaked, ${ }^{53}$ as Chad Gerber has very recently argued ([91], p. 149) in taking up Cipriani's case [22]. The second strophe introduces the Platonist distinction between the first One and second one, the basis of his trinitarian theology:

One the first, One arisen from itself, One before a one-you are God!

You go before any quantity [quantum], you are known by no boundaries.

Quantity is nothing in you, because no quantity is from you.

For the one born from you produces quantity rather than has it.

(Hymn I; [3], p. 284).

Here Victorinus seems to have his eye on those who objected to the homoousion on the grounds that ousia had strong material connotations. The denial of quantity in God serves those ends by maintaining the Platonist theological postulate of the divine as immaterial reality. The opening of the third strophe reiterates the presentation of the begetting of Christ as equivalent to movement from the pure One to the One-Being (or "One-Many" in Plotinus's locution ${ }^{54}$ ):

Hence the Father is unmeasured; measured and unmeasured is the Son.

You, Father, are One; there is One whom you begot, the Son.

(Hymn I; [3], p. 286).

The remainder of the hymns drifts into a sketch of the theology developed in the treatises. Victorinus concludes his reflections with a summary of his pro-Nicene theology:

All are then one by the Spirit, all are one by the light.

Hence to the individual persons, to the three, there is one true substance.

It has proceeded from the Father to the Son and has returned via the Spirit.

As the three individual persons exist, the three individuals are also in one.

This is the blessed trinity, this is the blessed unity.

(Hymn I; [3], p. 289).

The second and third hymns have a tighter form consisting of brief strophes and repetitive imprecations of prayer. The third hymn resembles the first in its philosophical language but maintains

52 In Hymn III Victorinus calls the Spirit conexio- "a connection is whatever connects two things"—-and complexio: "You are this third reality, the embrace of the two [complexio duorum], and this embrace differs in nothing from the One, because you make the two One" ([5], p. 303).

53 Augustine in De trinitate (XI 7. 12) calls the Spirit voluntas utrumque coniugens, "the will joining both" ([5], p. 573).

54 Plotinus, Enn. V 1. 8; ([82], vol. 5. p. 43). 
its formal structure of strophes ending with the refrain, O beata trinitas. This arrangement allows Victorinus to express his ideas in lapidary form, as we see in one of the more striking strophes of Hymn III:

God, you are substance, hidden away and in secret;

God, you are form, hidden away and in secret;

God, you are knowledge, hidden away and in secret.

Hence, God, you are the Pre-Being of all such Beings.

O blessed trinity!

(Hymn III; [3], p. 303).

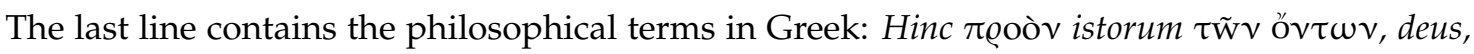
es. The istorum clarifies that the "Beings" here refer to the triad of substance, life, and knowledge, all of which Victorinus calls "God" to in indicate them as persons of the trinity. Yet God is "Pre-Being" of these Beings; and this is the dynamic of hidden movement and its manifestation noted by Hadot ([27], pp. 432-44) as one way Victorinus expresses the movement of the generation of the Son, or-in the language of the Parmenides - of the movement of the One-Being from the purely One. For example, the central idea of internal divine movement of the trinity the end of Hymn I quoted above is rendered with a triad reminiscent of Neoplatonist formulation: Status/Progressio/Regressus/O beata trinitas (Hymn III; [3], p. 297). ${ }^{55}$ These brief and even strophes fade away in the second part of the hymn where the philosophical language takes over; and the form is resumed in the last few strophes and end dramatically: "Free us/Save us/Justify us/O blessed Trinity!" (Hymn III; [3], p. 305).

The second hymn lacks the technical language and maintains a strict structure throughout. It consists of fifteen strophes, all of which begin with the familiar liturgical invocation of the Kyrie ${ }^{56}$ but in Latin: "Lord have mercy, Christ have mercy" (miserere domine, miserere Christe). This hymn is of particular interest on account of the autobiographical form of some of the strophes, which strike a note of personal piety amidst doctrinal formulations. The first two strophes of Hymn II illustrate the interweaving of personal and philosophical material:

Lord have mercy, Christ have mercy!

Have mercy, Lord,

Because I have trusted in you.

Have mercy, Lord,

Because by your mercy I have come to know you.

Lord have mercy, Christ have mercy!

You are the logos of my spirit!

You are the logos of my soul!

You are the logos of my flesh!

(Hymn II; [3], p. 290).

The notion that Christ is the "logos" (he uses the word in Greek) of the full human being follows from Victorinus' understanding of Genesis 1:26, discussed in Adv. Ar. IB (see Section 3 above). In Hymn II the three-fold division of the human being referenced in the second strophe here corresponds to Paul's three-fold division in the closing prayer of First Thessalonians (1 Thess 5:23), cited on Ephesians 5:30 ([6], p. 85). There he treats the apostle's mention of Christ's body, flesh, and bones as standing for the intelligible analogues of these components of the human being Christ as the logos possesses.

55 John Turner identifies this motif as borrowed from Neoplatonist treatment of the Chaldean Oracles and the arithmetic speculations of the Neopythagorean Moderatus of Gaza ([92], p. 223).

56 Noted by Clark ([4], p. 320). 
That Christ is "the logos of my flesh" means that this element of the human being has a spiritual form (and this is how Victorinus affirms the resurrection of the body). ${ }^{57}$

Strophes seven and eight of Hymn II contain key elements of Victorinus' anthropology with its characteristic mix of biblical and philosophical language:

Lord have mercy, Christ have mercy!

God, you have given me a soul,

But a soul is an image of life, for a soul lives.

May my soul live for eternity also.

Lord have mercy, Christ have mercy!

If it is in your likeness, God and Father,

And in the image of your Son that I have been made human,

May I, created thus, live for ages, because your Son has come to know me.

(Hymn II; [3], p. 291).

The final line of strophe eight is an allusion to part of Galatian 4:9 that suggests the key to salvation lies in being "known by God." His remarks on that verse in his Commentary on Galatians make clear what this hymn strongly hints, namely, the divine initiative in grace: "Now, because he said you have come to know God, or rather have come to be known by God, he preserves the integrity of his own precept: that those who come to Christ are those whom God sends, those whom God calls [cf. Rom 8:29-30]; and that those who know God are those whom God has known" ([6], p. 146).

Strophes nine and ten continue in the autobiographical voice and speak of a conversion in Johannine language:

Lord have mercy, Christ have mercy!

I loved the world, because you had made the world.

I have been detained by the world in the world's jealousy over your own.

Now I hate the world, because I have got a hold of the Spirit.

(Hymn II; [3], p. 291).

Lord have mercy, Christ have mercy!

Hasten to help the fallen, Lord, hasten to help those who are sorry.

For it a mystery that by your divine and holy judgment

I have sinned.

(Hymn II; [3], p. 292).

The twelfth and thirteen strophes provide interesting counterpoint in drawing on Paul's teaching about continual struggle against sin even on the part of the faithful (Rom 7:14-15):

Lord have mercy, Christ have mercy!

Long do I fight back, long do I resist my enemy.

But the flesh is still with me, the flesh in which the devil was overcome-

A great triumph for you, it gave us the bulwark of faith.

Lord have mercy, Christ have mercy!

The will to leave the world and its lands behind

Lies close to me.

57 Compare his comments In Phil. 4:7 ([6], p. 221) and his discussion in Adv. Ar. IB 64 ([3], p. 166), where he references 1 Cor 15: 51-53: "receiving a spiritual garment after the resurrection, 'we will be changed'." 
But to will without your aid, my plumage is too weak.

Give me the wings of faith, so I might fly to God above!

(Hymn II; [3], p. 292).

The remarkable note in the tenth strophe- "it is a mystery that...I have sinned"—-is difficult, as it is an isolated remark without parallel in his remaining works. As a reflex of his Platonism, it seems in line with Plotinus' discussion in Enn. I. 8. 6 of the relative non-existence of evil in comparison to the source of all being: "How can human wickedness be the contrary of that transcendent Good?" ([82], vol. 1, p. 293). Yet the "mystery" of sin may also allude to the puzzlement the apostle expressed in Romans 7:15 about compulsiveness of sin: "I do not understand what I am doing...."

The Hymns are thus a significant example of the amalgamation of language and imagery drawn from philosophical, creedal, and biblical—particularly Pauline and Johannine-elements. Frassinetti [17] has suggested that these verses prefigure elements of Augustine's Confessions; and one might well point to the opening prayer of Augustine's early work Soliloquies as an even closer parallel ([4], p. 322). Victorinus, like his pro-Nicene colleague Hilary, ${ }^{58}$ found it expedient to teach doctrine through hymns. The ostensibly autobiographical utterances in Hymn II are in any case a precious clue to his personal piety.

\section{Platonist Teaching on the Soul and Its Salvation}

Victorinus characterizes his work on the Pauline letters as "a simple exposition" or"a simple commentary" ${ }^{\prime \prime 9}$ and often refers to having treated topics at length elsewhere. He looks forward to a time when "with the permission of God" he might be "free from the necessity of interpreting the text" and directly discuss the ascent and descent of Christ at appropriate depth ([6], p. 60). Still, Victorinus finds occasions (on Gal 4:6, Eph 1:4, and Phil 2:6-11) to digress and inform his audience about the more recondite matters of the apostle's teachings. As Italo Mariotti has observed, this penchant for philosophical digressions seems to be "a constant of Victorinus' cultural character" ([93], p. 23), as we find a similar pattern of digressions in his commentary on Cicero. ${ }^{60}$

The preface to the commentary on De inventione contains brief reflections on key terms and the four general topics Cicero discusses about the relation between eloquence and virtue. Before addressing Cicero's text, Victorinus lays out what constitute "skilled knowledge" (ars) and how it differs from "virtue." Virtue he defines in an Aristotelian way as a "condition of the mind" (animi habitus), which he then describes in Stoic language as the mind being "in agreement with reason in the manner of nature" (in naturae modum). Reminding readers that "we consist of two things, soul and body," he clarifies that the natura in question that reason makes us conform to is the nature of the soul. He then proceed to a describe the soul with a Platonist commonplaces:

The soul [anima] is immortal. If it is immortal, it has descended from divine realities; if it has descended from divine realities, it is perfect [cf. Phaed. 246c]. But the acuity [acies] of the soul, however perfect it may be, is entangled and mired in a kind of thick coat of the body. Thus it comes about that the soul takes on a certain forgetfulness of itself. ([68], p. 155).

This last note about the soul's "forgetfulness of itself" (quandam oblivionem) corresponds to the "forgetfulness" of Phaedrus 248c, which Plato says is the cause of the soul's heaviness and the loss of its wings. Victorinus then relates how it is through "effort and training" (studio ac disciplina) that the soul is able to begin a process of recovery whereby it is uncovered and stripped (nudari). Only then, he says, "does the condition of the mind [animi habitus] get returned and recalled to the way of its own nature."

58 The three surviving genuine hymns of Hilary have been edited by A. Feder for the Vienna Corpus.

59 For discussion of what he means by these characterizations of his commentary my previous discussions ([7], pp. 110-14); [65], pp. 71-74).

60 Excellent account of the digressions in Lopetegui Semperena ([70], pp. 54-61). 
Victorinus goes to claim that Plato mentions various ways in soul's original "excellence" (virtus) can emerge: sometimes by skillful knowledge (arte) or because it is innate, and sometimes developed by exercise (exercitatione) or given by God ([68], p. 156). Victorinus returns to this in commenting on Cicero's text, reminding readers again that there once was "a better nature in human beings, but weighed down by the weakness of the body [oppressa corporis vitio], it declined into evil." It is the "great and wise person," who, having recognized that "good nature in human beings" was able by giving precepts to instruct them by disciplina in what he obtained fully by nature and practice ([68], p. 164). "What better cause could there be than to lead humans beings, who were living like animals, over to a human, even divine knowledge by means of useful and good precepts?" What Cicero meant by "the great and wise person" (De inv. I. 2), as Victorinus saw it, is anyone who can perform this task. He knows this is a minority view but he seem very assured of it: "A lot of people want the text to be understood as meaning Saturn, Plato, Aristotle and others, but they are wrong" ([68], p. 161). Inculcating good and useful precepts are likely something he saw himself as a professor of rhetoric doing, as I have elsewhere maintained ([8], pp. 10-15).

\subsection{World Soul and Worldly Souls}

The world soul was an important piece of Platonist piety that satisfied both intellectual and religious needs. The beautiful visible cosmos cannot be without an equally harmonious mind within, which is older than the body of the cosmos and the immanent source of its movement and life; and it is the best of all that has come into being (Plato, Tim. 36d-37a). This mind of the cosmos, or "the soul of the All" is a direct creation of the Demiurge (Intellect) and the source of the embodied souls created by the lesser gods into composite and mortal beings (Plato, Tim. 41d). The whole of the cosmos with its soul Plato called "the perceptible [aisthêtos] God" (Tim. 92c). Victorinus followed the Platonic doctrine of a world-soul to the point of including soul on an ontological level-the intellectibilia, or "intelligible realities"-located just below the level of the divine proper. This clearly undescended "soul" is described by Victorinus as a life-giving power possessed of its own To Be, To Live, and To Know (Adv. Ar. IB 63). It enacts on a lower level of being what the more divine life of nous does on the higher:

Just as the more divine unitary trinity...made by its radiance [effulgenter] the soul to be a subsisting reality, its own proper substance in the intelligible world...so too the Soul, a second unitary trinity, has unfurled its image-making power [imaginatio] in the sensory world—the same soul, which always existing above, gives birth to worldly souls. (Adv. Ar. IB 64; [3], p. 166).

That this is indeed the world-soul is evident by the distinction Victorinus makes between the "Soul...always existing above" and the "worldly souls" that have lost the heavenly seat. Just as on the level of the divine proper, the Son is the image of the Father and is life, so too "outside" the divine-figuratively speaking, as Victorinus did not think these realities are in space-comes Soul, "created [effecta] as an image of life," i.e., the life of the divine mind. Soul, retaining a trace of its prior-"its own nous, which is from the reality of Nous"-is what makes "the soul is a power of intelligent life" (Adv. Ar. IB 61; [3], pp. 161-62).

The individuation of worldly souls from Soul puts them in a different place, or rather in a place at all. Just as Soul imitates Intellect, so too souls get carried away by the power of life in them that images the great life above:

Tilting downward and away from Intellect [nous], soul drags itself and its intellect [nous] downwards.... If it fixes its gaze on inferiors-because it is wanton [petulans]—it becomes a life-giving power which makes the world and the things in the world to live, even a stone in the manner of stones. (Adv. Ar. IB 61; [3], p. 162).

This attention to the lower results in the soul becoming "shadowy" and it "is led downward." Whence embodied souls, composite entities. This fall from the heavenly realm occurs-with obvious parallels 
in Origen and Plotinus-through the soul's freedom (suae licentiae). Notwithstanding its "deprivation of the true light," the soul can be recalled to the higher realms "on account of the faint spark ${ }^{61}$ [scintillam tenuem] of its own nous" (Adv. Ar. IB 61; [3], p. 162). This is the doctrine informing Victorinus' notion of the soul as a being capable of spiritual transformation.

\subsection{The Place of Soul in Victorinus' Ontology}

Victorinus laid out his ontological schema of reality most fully in Ad Candidum 7, but his second response to Candidus contain additional illuminating imagery. After quoting Colossians 2:19 with its mention of "the whole body" to solve the question of what are the "all things" that are from Christ and God, Victorinus repels any thought that "the body of the whole universe" is like a pile of things united only by physical contiguity. Rather the whole universe is a self-contained body (continens corpus) like a chain (catena), in which all parts are interlinked (Adv. Ar. IA 25; [3], p. 99). "For there is a chain: God, Jesus, the Spirit, nous, soul, angels, and from there all corporeal beings." This is the "great chain of being" made famous by Arthur Lovejoy's 1936 title; and Victorinus' use of the image of a "chain" is earliest extant philosophical employment of this terminology, witnessed later in Macrobius (Somn. Scip. I. 14. 15) and probably deriving from Porphyry's commentary on the Chaldean Oracles ([30], p. 285). A similar idea occurs in Plotinus' treatise entitled On the Origin and Order of the Beings which Come after the First. ${ }^{62}$ Plotinus imagines the whole not as a chain but with another image of extension, even though he explicitly denies that Soul, like Intellect' is "in place": "It is then like a long life, stretched out at length; each part is different from that which comes next in order, but the whole is continuous with itself" (V. 2. 2). ${ }^{63}$ Any such hierarchical image implying descending ontological levels in the divine is theologically incorrect for a Nicene Christian. Victorinus' list has Jesus notched below God and followed by the Spirit and nous, but he ignores the subordinationalist implication. Below nous in Victorinus' chain comes "Soul and angels," in that order: the Soul is the third principle in adherence to Platonist doctrine.${ }^{64}$ After angels come corporalia omnia, anything that has or is a body.

Victorinus begins his ontological account in Ad Candidum 7 by mentioning realities that belong to the divine esse: there are "things which really exist," which he refers to as a class of intellectibilia or "knowable realities" that comprise a triple realm. This triple realm itself has three levels. First is "the one and only Being" [öv]. Next is the triad existentialitas vitalitas, intelligentitas: "power of being, power of living, and power of understanding." Just below this triad Victorinus lists a third species of intellectibilia, which he calls "supercelestials": "spirit, nous, soul, knowledge, training, powers, logoi, opinions, perfection, existence, life, and thinking." Despite the nomenclature of the first two terms, these items do not belong to the divine trinity. Victorinus treats them as objects constituting an intelligible realm to which "our nous" can ascend, be formed by and thus emerge from the "confusion characteristic of seeking" to stand on its own thought (Ad Cand. 7; [3], p. 22). The term "supercelestial" indicates they are "above" the material heavens and thus part of the (non-local) spiritual reality. The names of these supercelestials suggest that they are forms of the spiritual components of the human creature and functions as the guiding lights for souls who wander in the realm of the senses.

Individual souls Victorinus classifies as intellectualia - beings capable of understanding - who receive proper orientation from higher knowable realities (intellectibilia). While these latter are "things which truly exist," souls qua intellectualia are "things which just exist" (Ad Cand. 8; [3], p. 23). The next level, "the things which are not truly non-existents," is realm including "the whole world consisting of matter and form in a state of mixture" (Ad Cand. 9; [3], p. 26). Matter (hulê) alone he puts under the category of "things which are not": it is sterile and "unproductive" (effeta) without the power of soul (Ad Cand. 10; [3], p. 28). Alone it is "indeterminate," as it is nothing but the substrate (subiectum) of

61 The notion of the scintilla animae took on great significance in Meister Eckhart and other medieval mystics [94].

62 This is a treatise Victorinus clearly knew well, as he inserted its the first sentence into $A d v$. Ar. IV 2 (see n. 11 above).

63 Translated by Armstrong ([82], vol. 5, p. 65).

64 See Plotinus' reference in V. 1.8 to the three kings of Plato's Ep. 2 (312E). 
its qualities, which bestow determinate form upon the matter; only when thus qualified it is called anything-"fire, air, water, earth" (Ad Cand. 10; [3], p. 27). When soul is "mixed with hulê it is among the things which are not truly not being," Yet Victorinus says both soul and matter are omnium nutrix, "the nurse of all thing" (Ad Cand. 10; [3], p. 28), with a clear allusion to Plato's famous description in Timaeus 49A of the place of creation - which later Platonists ${ }^{65}$ identified with unformed matter-as "the receptacle of all generation, like a nurse." Soul and matter have in common the fact that they are necessary components of composite beings and take the qualities of what they are mixed with.

As embodied intellectualia, human souls have sense-perception (sensus). This cognitive power has a dual capacity. The lower, material nous (discussed above in §2) operates "by means of sense-perception in its imitation of intellectual activity"; sense perception is actually "a copy [simulacrum] of Intellect" (Ad Cand. 9; [3], p. 25). But sense-perception is capable of transformation: when it "fully grasps the activity of Intellect ...it becomes similar and akin to a pure intellect, the sort that comprehends the heavenly bodies, the aetherial realm, and the things born and reborn in nature and matter." We are retracing the complex of issues Victorinus raised in the opening of Ad Candidum (discussed in $\$ 3$ above) and in his commentary on Cicero: how the original nature of the can be recovered from the difficulties besetting embodied souls. Left to its own devices, sense-perception grasps "nothing but qualities, neither perceiving nor comprehending the underlying thing [subiectum], that is, the substance" (Ad Cand. 9; [3], p. 26). The senses along do not provide sufficient orientation to worldly souls.

\subsection{Salvation of the Soul}

The lengthiest of Victorinus' philosophical discussions in his commentaries on Paul occurs in his treatment of Ephesians 1:4-8 ([6], pp. 6-16). ${ }^{66}$ The occasion for the digression is the assertion of v. 4 that God "chose us in him [Christ] before the foundation of the world that we might be holy." The most obvious Platonist aspect of Victorinus' discussion is his assertion that souls exist prior to embodiment. ${ }^{67}$ Plato asserted this in a number of dialogues (Phaed. 87D, 62B; Phaedr. 246C; et al.), and Plotinus developed these suggestions at length in his treatise On the Descent of Souls into Bodies (IV. 8). Victorinus seems to have felt there was nothing inherent in Christianity that prevented an importation of Platonist teachings on the soul. His opening comment on Eph 1:4 sums up the conclusions he derived from his analysis of the epistolary text:

This is a treatment of the divine reality [de divinitate], a short explanation of the whole Mystery, where these things are established: that Christ existed before the world; that the world has been made; that there were souls before the world; that the world exists by God's dispensation; that souls both came into the world and are being freed from the world by God's dispensation; that all that is done is the will of God; and that for those living in accordance with Christ there is a reward so that sins may be forgiven and we may participate in the glory of God. ([6], p. 6).

Notable is the three-fold structure of the drama of the soul: from existence before the world, to worldly existence, to a freeing from the world. Victorinus' formulation of the final goal of the soul's life as a participation "in the glory of God" combines the Christian image of believers hoping to behold the glory of God (John 1:14, etc.; 2 Cor 3:18) with Platonist language of participation or sharing in the divine life (cf. Plutarch, Plat. quaest. 1001C; Plotinus, IV 7.10). Victorinus grants that these items he has laid out in this preliminary way are "obscure [occulta] but are still completely true" ([6], p. 6).

The exposition of the truths Victorinus thinks the apostle is related brings us into the heart of what German scholarship calls his Seelenmetaphysik, "metaphysics of the soul." This aspect of Victorinus' thought was discussed fully in the admirable 1936 study of Hubert de Leusse [96], the

65 E.g., Apuleius, De Plat. 1.5.

66 Translation in ([8], pp. 46-54).

67 For discussion of the Platonist background, see John Dillon [95]. 
1990 dissertation of Werner Steinmann [97], and in my translation of Victorinus' commentary on Ephesians ([8], pp. 46-54). Here our discussion focuses on several features of the comments on Eph 1:4-8 that complement his discussions of the soul laid out in the preceding sections.

Victorinus' comments on Eph 1:4 begin with an account of the soul's pre-existent condition, where he shows that the text supports the view of the soul's existence prior to the world:

In the first place, therefore, let us examine what the apostle has just said: "God chose us." Clearly, God chose us when we already existed and chose us in Christ, so both we and Christ existed before. ...Therefore we were spiritual beings, if we were in Christ. And if we were in Christ and were spiritual beings, we existed—as Paul adds afterward—“before the foundation of the world". ([6], p. 7).

Victorinus turns to the question that animated Plotinus' discussion of the soul's descent. Like Plotinus (IV 8. 2), he does not blame God or suppose that the descent was penal:

Now why has the world been founded? And why did many things come hither into the world? Although the souls and other powers of this sort had been established, as I said, in Christ, this is a lesser kind of perfection-unless the souls should know by experience all things capable of existing, would come to recognize in this way what is to be pursued, would see what is to be chosen, and would follow in the Spirit that is indeed Christ. Souls exist by their own force and by their prepotency: they are not this very thing which is spirit but exist so as to be able to receive spirit. Still, insofar as they are souls, they are not yet spirits. ([6], p. 8).

Victorinus conceives the soul's dwelling in the body as a necessary path to the actualization its creaturely capacities (this is very close to Plotinus IV 8. 5). However, worldly souls must meet the challenges that face them as composite entities:

Although in accordance with its intellect [secundum intellectum] the soul is a powerful being [potens], the intellect can nonetheless be mistaken unless it also knows that which imitates it but is not in fact intellect. If, I say, the soul should become aware of what causes mistakes, what lies and deceives, and should recognize, repudiate and flee it as it were an enemy or a deceiver, the soul will easily keep itself together and recognize its own excellence. The soul will be full and perfected in Christ, meaning it will be spiritual. ([6], p. 8).

But what is the imitator of "understanding" (intellegentia = the image of nous that is present in embodied soul) that so deceives souls? As in the passage from Ad Cand. 9 discussed above, the problem is the unreliability of sense-perception as a power geared toward knowing inherently unstable material reality, an old Platonist saw if ever:

But what sort of thing is it that creates a likeness of the faculty of understanding [similitudinem intelligentiae] and deceives sense perception, which exists only in the things of the world and in what the Greeks call hylê or matter? For through the fleshly apertures and the powers of perceptual activity a kind of false intellect is born. With many a trick it deceives the true faculty of understanding and in some way damages the truth by means of images. Therefore although the soul is by nature so disposed as to be capable of understanding, the faculty of understanding could nonetheless easily slip and fall into a nearby power and then into an image of understanding, into sense perception, which is in the world and is altogether from nature. ([6], p. 8). 
This mention of "nature" one of the few places where he uses the term to apply to what in Plotinus' view was the level of reality below soul. ${ }^{68}$ In Victorinus' Christian conception, however, the realm of nature is part of the divine plan:

The world has been made by the work and will of God, and all things have been constructed in matter, so that the soul, having been detained [anima detenta] by these things, might recognize what the senses are and how much they are worth. ([6], p. 9).

The material realm is a kind of training-ground for lost souls, a conception decidedly more Platonist than biblical. Yet the remark that follows brings the reader back into the world of the Bible: "The Law and its admonitions have been given by God in order that God-and also what is not of God-be recognized" ([8], p. 8). The conclusion of this passage makes it clear that Victorinus the commentator on Paul is working with a model of divine intervention signally different from anything in Platonist thought: the incarnation. The diagnosis of the problem, however, is pure Platonism:

Nonetheless, because souls overcome by sensual powers had nothing in mind but the world, matter, flesh and body; and because they believed that these things alone were real (and nor were they up to the task of overcoming and breaking the chains that bind the soul), by the power and the will of God-that He might free them from the senses and the deceitful world-God sent His son our Lord the Savior, Christ, the Holy Spirit. Thus once the Mystery was made manifest, Christ would in the first place teach [doceret] what the Father is, then what the Spirit is and what it is to live spiritually: what the soul ought to pursue and what is foreign to it, as I have taught. For this is the strength of the Christian: to discern and separate out these things: what is eternal and what mortal, what leads to destruction and what to salvation. ([8], p. 9).

"Mystery" is Victorinus' word for the entirety of the Christ-event: the fact that "by his flesh, cross, death and resurrection, help has come to souls." Such help, as he adds here, is available to soul "if faith in Christ is taken up" ([8], p. 9).

Victorinus' presentation of the incarnate Christ as intervening to teach (doceret) souls the necessary elements of ethics and physics-i.e., philosophy, according to the definition he gave commenting on Cicero-led Schmid to judge that despite Victorinus' verbal emphasis upon grace, his theology was "naively Pelagian" ([15], p. 64). Werner Erdt, however, has examined this same question at length ([98], pp. 139-73) and concluded that for Victorinus "the human will is free with respect to believing in Christ, but in itself unfree with respect to doing acts of love." In a recent article, Dongsun Cho has also opposed Schmid's judgment vigorously, arguing that "Victorinus tries to preserve the paradoxical relationship between faith as a human obligation and faith as a free gift of God" ([99], p. 13). Cho points to Victorinus' comment on Galatians 5:8 as a clear place where God's initiative in predestining and calling souls is what results in people having being persuaded to faith.

As I have previously maintained, one need not make the case that Victorinus was "Augustine before Augustine" to appreciate that his theology of justification was a faithful reading of Paul's assertion of the primacy of divine grace in salvation ([7], pp. 148-70). Victorinus did not think the incarnate Logos was just a particularly persuasive teacher. The Pauline themes are not forgotten. Hymn II, whether genuinely autobiographical or not, shows he assumed the presence of sin even in believers and the necessity of forgiveness. His comments on Ephesians 1:7 present his atonement theology:

For this is grace: that in Christ "through his blood" we have "redemption" and "the remission of sins"; that our sins are even remitted for us through the fact that he was crucified by the Law. For this is what "through his blood" means. ([6], p. 14).

68 See Dominic O'Meara discussion of Plotinus' conception of the relation between soul, matter, and the nature in ([9], pp. 313-14). 
The fact of his death-his blood-is what makes for the remission of sins. That he was crucified lege, "by the Law" (cf. John 19:7), suggests it was Christ's being executed a guilty (though innocent) that allows others to be count as innocent who deserve death. Victorinus' remarks on Galatians 2:12 support the notion that he followed traditional atonement theology. ${ }^{69}$ His further comments on Ephesians 1:7 spell out what atonement frees believers for in broad Platonist strokes:

Christ himself has redeemed us from death-that is, from fleshly thoughts and desires-and has made us his servants, that is, made us to serve him. This means to live now spiritually: to do nothing in a fleshly way and to be in no way affected by the senses, but rather to turn altogether toward God, to tread down all earthly things and to seek again our source. ([6], p. 14).

Victorinus goes on to clarify that having been redeemed by Christ, "we are led back to the pristine nature [naturam illam pristinam] that belonged to us from God." It is this that allows believers to "live now spiritually" and be "sons of God but through adoption"-once sins sins have been remitted. He then returns to the phrase per sanguinem of the verse and makes programmatic statements about what is owing to God in salvation and what is up to us:

For it is not by means of our own power [virtute nostra] that we have been turned back to spirit: we also have received the Spirit of Christ through the blood of Christ [per sanguinem Christi ${ }^{70}$ spiritum accepimus]. Therefore, our sins are remitted us and are forgiven through the grace of God; we do not abandon them by our own power. This alone belongs to our power: to believe Christ and to live spiritually for the sake of Christ. ([6], p. 14).

Victorinus clearly believes that the divine initiative in Christ precedes faith and the spiritual life. The nature of Christian hope, as he says on Galatians 5:3, is "hope in the Spirit, in faith, and in the justification of God; our hope is not based on works." What is hoped for is "eternal life" which-he is again careful to gloss- "would be supplied...we on the basis of God's grace, not works or merits. But this happens through the Spirit" ([6], pp. 159-60). ${ }^{71}$

The emphasis on hope and faith as rooted in God's action is the biblical element apparent throughout his commentaries on Paul. "Hope in the Spirit," as I read it in light of the discussion above about the soul's struggle in the world, refers precisely to the inner process whereby the soul's higher faculties are activated by the Spirit. The Platonist element in this is sufficiently clear, as is the Christian context in which we find it in Victorinus: the soul can ascend to higher realities based on its ontological structure-it is the only creature with this transformable capacity ${ }^{72}$-but for this it requires enlightenment, ethical-ascetic practice, and the gracious condescension of the divine.

\section{Conclusions}

This examination of Platonist ideas and motifs in central aspects of Marius Victorinus' theology—his doctrine of God, and his teachings on the soul and its salvation—reveals a comprehensive and thorough fusion of philosophical thought and Christian convictions. The degree of interpenetration of philosophical and Christian thought suggests that it would be inadequate to conclude that the Platonism functions merely to express dogma, as if Victorinus had somehow taken hold of the faith and subsequently sought to render it comprehensible. A more adequate model would be one in which Christianity was attractive to Victorinus as a unique package with charms of its own, chiefly, the Pauline

69 In Eph. 2:21: "That would be ungrateful to the one who did so much for me, who for my sake would put himself in the line of fire in order to liberate me from my sins by taking their penalties upon himself" ([6], p. 125).

70 I taken Christi with both nouns, since Victorinus makes in clear in his comments on Gal 4:6 that it is "the Spirit of his own Son who is the Holy Spirit, who descending into our hearts easily makes the Father known" ([6], p. 143).

71 See my discussion of this passage ([7], p. 330).

72 See Victorinus' remarks on Eph 1:8 ([6], p. 15), translation in ([8], pp. 53-54). 
soteriology with its doctrine of grace and accompanying piety. The church, in this telling, will have been found by Victorinus to contain a more satisfactory cultural synthesis of the intellectual, ethical, and religious concerns he previously held and expressed in his rhetorical teaching and engagement with Platonism.

On the long debated question of whether and to what extent Platonism has contributed to Christian thought, I think we do well to attend to the five points of shared conviction that C. J. Vogel ([66], pp. 54-55) has articulated in formulating a positive response to this question:

(a) that visible things are no primary reality, existing by and through themselves;

(b) that by their imperfection visible things point to and require a perfect and absolute reality, primary being and founded in itself;

(c) that this invisible reality is of an infinitely higher significance and value than that of visible things depending on it;

(d) that this fundamental fact has to rule our life and conduct;

(e) that it implies the infinite value of the human soul, and therefore, of the individual person.

All of these positions occur with equal conviction, unless I err, in Victorinus, Augustine, Aquinas, and countless other theologians of the Abrahamic religions. It does not seem to me, however, that any form of modern thought has appeared as an apt substitute for Platonism in providing philosophical grounds for these five points that are expressed in a variety of genres of biblical writings.

In the annals of Platonist Christianity, Victorinus' thought is major milestone, exceptional not in kind but in degree and accordingly comparable to the most philosophical Greek theologians of early Christianity: Origen, Gregory of Nyssa, and pseudo-Dionysius. Like them, Victorinus was the inheritor and promulgator of a rich development of the Platonic tradition that had long incorporated Aristotelian and Stoic elements and taken a religious turn to "philosophical gnosis."73 The blending of biblical religion and Greek philosophy, however, ultimately goes back to the Alexandrian Jew Philo, who explicitly identified the biblical God with the first God of Platonism. Philo developed a doctrine of radical divine transcendence with the help of philosophical resources of the early first century CE [101]. God, Philo asserted, is "better than the good, purer than the One and more primordial than the Monad" (Con. Vita I 2; [102], p. 115). On the pagan side, this identification of the God of the Bible with the First God was accepted by Numenius of Apamaea [103]. Numenius made the important step-as Peter Van Nuffelen has noted-of establishing "religion and philosophy as two parallel sources of truth, with the latter in its Platonist form being the measure of truthfulness in the former" ([104], p. 79). What we find in Marius Victorinus' works is the converse of what Van Nuffelen has identified as Numenius' working principle. Victorinus persistently, if not always in a fully consistent way, brought Platonist ideas into the service of Nicene orthodoxy. The clearest expressions of this move are his insistence on calling God by the biblical term "Spirit" and by appropriation of a hierarchical theology to fit the needs of pro-Nicene theology that eschewed any gradations of divinity. ${ }^{74}$ It is too little appreciated that the ubiquitous modern use of the word "spirit" and "spiritual" to signal an irreducible aspect of human life depends on the theological transformations of Platonist ideas and language by Christian thinkers.

Soteriology is the other great area where Victorinus' Platonist learning allowed him to formulate what the educated of his time would have recognized as a scientific understanding of how souls could emerge from their prodigal erring to regain the heavenly seat. The freedom with which he interpreted Christianity in light of Platonist teachings about the soul was possible, because prior to the Origenist controversy, there were no doctrinal parameters about what could be said in this regard. Yet Victorinus' readiness to bring Platonist thinking en masse into the Christian fold should not obscure the fact that

73 Thus John Dillon describing Plutarch's philosophy ([100], p. 216).

74 This point has recently been perspicaciously discussed by Alexey Fokin [58]. 
he regarded the church, its canon, and its creed as fully authoritative. In the end, Victorinus followed Christ but was happy to bring what truth Plato and his followers had been able to discover apart from the revelation of the Mystery in the gospel.

Conflicts of Interest: The author declares no conflict of interest.

\section{References}

1. Travis, Albert H. “Marius Victorinus: A Biographical Note." Harvard Theological Review 36 (1943): 83-90. [CrossRef]

2. Hadot, Pierre. Marius Victorinus: Recherches sur sa vie et ses œuvres. Paris: Études Augustiniennes, 1971.

3. Henry, Paul, and Pierre Hadot, eds. Marii Victorini opera pars I: Opera theologica. CSEL 83/1. Vienna: Hoelder-Pichler-Tempsky, 1971.

4. Victorinus, Marius. Theological Treatises on the Trinity. Translated by Mary T. Clark. Washington: Catholic University of America Press, 1981.

5. Victorinus, Marius. Opere teologiche di Mario Vittorino. Translated by Claudio Moreschini and Chiara Ombretta Tommasi. Turin: Unione Tipografica-Editrice Torinese, 2007.

6. Gori, Franco, ed. Marii Victorini opera pars II: opera exegetica. CSEL 83/2. Vienna: Hoelder-Pichler-Tempsky, 1986.

7. Cooper, Stephen A. Marius Victorinus' Commentary on Galatians. Oxford: Oxford University Press, 2005.

8. Cooper, Stephen A. Metaphysics and Morals in Marius Victorinus' Commentary on the Letter to the Ephesians. American University Studies. Frankfurt am Main: Peter Lang, 1995.

9. Gerson, Lloyd, ed. Cambridge History of Philosophy in Late Antiquity. Cambridge: Cambridge University Press, 2010.

10. Courcelle, Pierre. Recherches sur les Confessions de saint Augustin. Paris: E. de Boccard, 1950.

11. Moreschini, Claudio. "Boezio e la tradizione del neoplatonismo latino." In Varia Boethiana. Naples: M. D'Auria, 2003, pp. 7-30.

12. Gore, Charles. "Victorinus (6)." In Dictionary of Christian Biography. Edited by William Smith and Henry Wace. London: J. Murray, 1877-87, vol. 4, pp. 1129-38.

13. Harnack, Adolf. History of Dogma, 3rd ed. Translated by James Millar. London: Williams \& Norgate, 1898, vol. 5.

14. Koffmane, Gustav. De Mario Victorino philosopho christiano. Bratislava: H. Lindner, 1880.

15. Schmid, Reinhold. Marius Victorinus Rhetor und seine Beziehungen zu Augustin. Kiel: Uebermuth, 1895.

16. Van der Lof, L. J. "De Invloed van Marius Victorinus Rhetor op Augustinus." Nederlands Theologisch Tijdschrift 5 (1950-1951): 287-307.

17. Frassinetti, Paolo. "Le Confessioni agostinianae e un inno di Mario Vittorino." Giornale italiano di filologia 2 (1949): 50-59.

18. Hadot, Pierre. "L'image de la Trinité dans l'âme chez Victorinus et chez saint Augustin." Studia Patristica 6 (1962): 409-42.

19. Sciuto, Italo. "S. Agostino e Mario Vittorino: alcuni motivi di confronto." Augustinus 39 (1994): 493-508.

20. Girgenti, Giuseppe. "L'identità di uno ed essere nel Commentario al Parmenide di Porfirio e la recezione in Vittorino, Boezio e Agostino." Rivista di filosofia neo-scolastica 86 (1994): 665-88.

21. Plumer, Eric. Augustine's Commentary on Galatians: Introduction, Text, Translation, and Notes. Oxford: Oxford University Press, 2002.

22. Cipriani, Nello. "Le fonti cristiani della dottrina trinitaria nei primi Dialoghi di S. Agostino." Augustinianum 34 (1994): 253-312. [CrossRef]

23. Cipriani, Nello. "La retractatio agostiniana sulla processione-generazione dello Spirito Santo (Trin. 5, 12, 13)." Augustinianum 37 (1997): 431-39. [CrossRef]

24. Cipriani, Nello. "Agostino lettore dei Commentari paolini di Mario Vitttorino." Augustinianum 38 (1998): 413-28. [CrossRef]

25. Cipriani, Nello. "La presenza di Mario Vittorino nella riflessione trinitaria di S. Agostino." Augustinianum 42 (2002): 261-313. [CrossRef]

26. Wear, Sarah Klitenic. "Activity and Potentiality in Augustine and Victorinus' Use of Jn 5:19." Quaestiones Disputatae 2 (2011): 107-17. [CrossRef] 
27. Hadot, Pierre. Porphyre et Victorinus. Paris: Études Augustiniennes, 1968, vol. 2.

28. Henry, Paul. Plotin et l'Occident: Firmicus Maternus, Marius Victorinus, Saint Augustin et Macrobe. Louvain: Spicilegium Sacrum Lovaniense Bureaux, 1934.

29. Henry, Paul. “Marius Victorinus, a-t-il lu les Ennéades de Plotin?" Recherches de science religieuse 24 (1934): 432-49.

30. Theiler, Willy. "Die chaldäischen Orakel und die Hymnen des Synesios." In Forschungen zum Neuplatonismus. Berlin: De Gruyter, 1966, pp. 252-301.

31. Saffrey, H. D. "Connaissance et inconnaissance de Dieu: Porphyre et la Théosophie de Tuubingen." In Recherches sur le néoplatonisme après Plotin. Paris: J. Vrin, 1990, pp. 11-25.

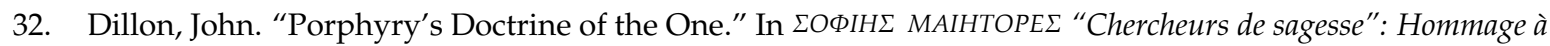
Jean Pepin. Edited by M.-O. Goulet-Cazé, G. Madec and D. O’Brien. Paris: Persée, 1992, pp. 356-66.

33. Majercik, Ruth. "Chaldean Triads in Neoplatonic Exegesis: Some Reconsiderations." Classical Quarterly 51 (2001): 265-96. [CrossRef]

34. Zambon, Marco. Porphyre et le moyen-platonisme. Paris: Vrin, 2002.

35. Linguiti, Alessandro. "Commentarium in Platonis Parmenidem." In Corpus dei papiri filosofici greci e latini: Part III, Commentari. Florence: Olschki, 1995, pp. 63-200.

36. Smith, Andrew. "Porphyry: Scope for a Reassessment." In Studies on Porphyry. Edited by George Karamanolis and Anne Shepherd. London: Institute of Classical Studies, 2007, pp. 7-16.

37. Baltes, Matthias. Marius Victorinus: Zur Philosophie in seinen theologischen Schriften. Leipzig and Munich: K. G. Saur, 2002.

38. Bechtle, Gerald. The Anonymous Commentary on Plato's "Parmenides". Bern: Haupt, 1999.

39. Corrigan, Kevin. "Platonism and Gnosticism. The Anonymous Commentary on the Parmenides: Middle or Neoplatonic?" In Gnosticism and Later Platonism: Themes, Figures, and Texts. Edited by John Turner and Ruth Majercik. Atlanta: Society of Biblical Literature, 2000, pp. 141-77.

40. Majercik, Ruth. "Porphyry and Gnosticism." Classical Quarterly 55 (2005): 277-92. [CrossRef]

41. Turner, John. D., and Kevin Corrigan, eds. Plato's Parmenides and its Heritage: Volume II. Atlanta: SBL, 2010.

42. Drecoll, Volker Henning. "Is Porphyry the Source Used by Marius Victorinus?" In Plato's Parmenides and Its Heritage: Volume II. Atlanta: SBL, 2010, pp. 65-80.

43. Hadot, Pierre. "Porphyre et Victorinus': Questions et hypothèses." Res Orientales 10 (1996): 117-57.

44. Tardieu, Michel. "Recherches sur la formation de l'Apocalypse de Zostrien et les sources de Marius Victorinus." Res Orientales 10 (1996): 1-114.

45. Barry, C., W.-P. Funk, P.-H. Poirier, and J. D. Turner, eds. Zostrien (NH VIII, 1). Bibliothèque copte de Nag Hammadi, Section “Textes” 24. Québec: Presses de l’Université Laval, 2000.

46. Bechtle, Gerald. “A Neglected Testimonium (Fragment?) on the Chaldean Oracles.” Classical Quarterly 56 (2006): 563-81. [CrossRef]

47. Tommasi, Chiara O. “Tripotens in unalitate spiritus.” Koinōnia 20 (1996): 52-75.

48. Tommasi, Chiara O. "L'androginia di Cristo-Logos: Mario Vittorino tra platonismo e gnosi." Cassiodorus 4 (1998): 11-46.

49. Tommasi, Chiara O. "Viae negationis della dossologia divina nel medioplatonismo e nello gnosticismo Sethiano (con echi in Mario Vittorino)." In Arrhetos Theos. L'ineffabilità del primo principio nel Medioplatonismo. Edited by Francesca Calabi. Pisa: ETS, 2002, pp. 119-54.

50. Tommasi, Chiara O. "Silenzio, voce, annunzio: la trinità secondo Mario Vittorino." In Silenzio e parola. Rome: Institutum Patristicum Augustinianum, 2012, pp. 521-53.

51. Orbe, Antonio. Hacia la primera teología de la procesión del Verbo. Estudios Valentinianos, Volume 1. Rome: Universitas Gregoriana, 1958, pp. 490-503.

52. Thomassen, Einar. "The structure of the transcendent world in the Tripartite Tractate (NHC I, 5)." Vigiliae Christianae 34 (1980): 358-75. [CrossRef]

53. Turner, John. "Victorinus, Parmenides Commentaries and the Platonizing Sethian Treatises." In Platonisms: Ancient, Modern, and Postmodern. Edited by Kevin Corrigan and John D. Turner. Leiden: Brill, 2006, pp. 55-96.

54. Turner, John. "The Platonizing Sethian Treatises, Marius Victorinus's Philosophical Sources, And Pre-Plotinian Parmenides Commentaries." In Plato's Parmenides and its Heritage. Atlanta: SBL, 2010, vol. 1, pp. 131-72. 
55. Trego, Kristell. “Présentation. À la mémoire de Pierre Hadot.” Les Études philosophiques 101 (2012): 147-49. [CrossRef]

56. Cazelais, Serge. "Prière, élévation spirituelle et connaissance de Dieu chez Marius Victorinus." Dionysius 29 (2011): 157-70.

57. Fokin, Alexey. "Elements of Apophatic Theology in Writings of Marius Victorinus." In Silenzio e parola. Rome: Institutum Patristicum Augustinianum, 2012, pp. 509-20.

58. Fokin, Alexey. "The Doctrine of the 'Intelligible Triad' in Neoplatonism and Patristics." Studia Patristica 58 (2013): 45-72.

59. Němec, Václav. "Die Theorie des göttlichen Selbstbewusstseins im Anonymen Parmenides-Kommentar." Rheinisches Museum 154 (2011): 185-205.

60. Němec, Václav. "Zum Problem der Gattung des Seienden bei Marius Victorinus und im antiken Neuplatonismus." Rheinisches Museum, forthcoming, in press.

61. Karfíková, Lenka. "Semet ipsum exinanivit: Der Logos-Erlöser nach Marius Victorinus." In Für uns und für unser Heil: Soteriologie in Ost und West. Edited by Theresia Hainthaler. Wien: Tirolia, 2014, pp. 127-50.

62. Vasiliu, Anca. "Relation absolue et relation relative. La Trinité selon Basile de Césarée et Marius Victorinus." Quaestio 13 (2013): 73-101. [CrossRef]

63. Vasiliu, Anca. "L'argument de l'image dans la défense de la consubstantialité par Marius Victorinus." Les Études philosophiques 101 (2012): 191-216. [CrossRef]

64. Cooper, Stephen. "Marius Victorinus." In Cambridge History of Philosophy in Late Antiquity. Cambridge: Cambridge University Press, 2010, pp. 538-51.

65. Cooper, Stephen. "Philosophical Exegesis in Marius Victorinus' Commentaries on Paul." In Interpreting the Bible and Aristotle in Late Antiquity: The Alexandrian Commentary Tradition from Rome to Baghdad. Edited by Josef Lössl and John Watt. Farnham: Ashgate, 2011, pp. 67-89.

66. De Vogel, C. J. "Platonism and Christianity: mere antagonism or a profound common ground?" Vigiliae Christianae 39 (1985): 1-62. [CrossRef]

67. Moreschini, Claudio. "Limiti e cosistenza del platonismo cristiano." In Neoplatonismo pagano vs. neoplatonismo cristiano: Identità e intersezioni. Edited by Maria Di Pasquale Barbanti and Concetto Martello. Catania: CUECM, 2006, pp. 33-64.

68. Victorinus, Marius. "Explanationum in rhetoricam M. Tullii Ciceronis libri duo." In Rhetores latini minores. Edited by Carolus Halm. Leipzig: Teubner, 1863, pp. 155-304.

69. Ward, John. "From Antiquity to the Renaissance: Glosses and Commentaries on Cicero's Rhetorica." In Medieval Eloquence. Studies in the Theory and Practice of Medieval Rhetoric. Edited by James J. Murphy. Berkeley: University of California Press, 1978, pp. 25-67.

70. Lopetegui Semperena, Guadalupe. “El comentario de Mario Victorino al De inventione de Cicerón.” Logo 3 (2004): 43-62.

71. Gersh, Stephen. Middle Platonism and Neoplatonism: The Latin Tradition. 2 vols. Notre Dame: University of Notre Dame Press, 1986.

72. Bergner, Karlhermann. Der Sapientia-Begriff im Kommentar des Marius Victorinus zu Ciceros Jugendwerk De inventione. Frankfurt: Peter Lang, 1994.

73. Hadot, Pierre. "Les divisions des parties de la philosophie dans l'antiquitè." Museum Helveticum 36 (1979): 201-23.

74. Courcelle, Pierre. Late Latin Writers and their Greek Sources, 2nd French ed. Translated by Harry E. Wedeck. Cambridge: Harvard University Press, 1969.

75. Smith, Andrew, and David Wasserstein, eds. Porphyrii philosophi fragmenta. Stuttgart: Teubner, 1993.

76. Augustine. Confessions. Translated by Henry Chadwick. Oxford: Oxford University Press, 1998.

77. Courcelle, Pierre. "Parietes faciunt christianos?" In Mélanges d'archéologie, d'épigraphie et d'histoire offerts à Jérôme Carcopino. Paris: Librairie Hachette, 1966, pp. 241-48.

78. Bouton-Toubloulic, Anne-Isabelle. "Deux interprétations du scepticisme Marius Victorinus et Augustin." Les Études philosophiques 101 (2012): 217-32. [CrossRef]

79. Pronay, Andreas. Marius Victorinus: Liber de definitionibus. Eine spätantike Theorie der Definition und des Definierens. Studien zur klassischen Philologie. Frankfurt: Peter Lang, 1997.

80. Corsini, Maria Patrizia. "Il logos nell'opera di Caio Mario Vittorino: verbo creatore e discorso." Annali dell'Istituto Italiano per gli Studi Storici 3 (1995-1996): 149-210. 
81. Chadwick, Henry. The Church in Society: From Galilee to Gregory the Great. Oxford: Oxford University Press, 2001.

82. Plotinus. Plotinus: Volume VII. Translated by Arthur Hilary Armstrong. Cambridge: Harvard University Press, 1966-1988.

83. Majercik, Ruth. The Chaldean Oracles: Text, Translation, and Commentary. Leiden: Brill, 1989.

84. Hanson, R. P. C. The Search for the Christian Doctrine of God. Edinburgh: T\&T Clark, 1988.

85. Edwards, Mark J. “Marius Victorinus and the Homoousion." Studia Patristica 46 (2010): 105-18.

86. Victorinus, Marius. Christlicher Platonismus: Die theologischen Schriften des Marius Victorinus. Translated by Pierre Hadot and Ursula Brenke. Zürich: Artemis, 1967.

87. Stefani, Massimo. "Sull'antropologia di Mario Vittorino (La 'discesa' vivificante dell'anima in prospettiva cosmologica)." Scripta theologica 19 (1987): 63-111.

88. Metzger, Michael D. "Marius Victorinus and the substantive infinitive." Eranos 72 (1974): 65-77.

89. Hoslip, Ian. “Victorinus and the Imago Dei." Blackfriars 25 (1944): 429-34. [CrossRef]

90. Di Berardino, Angelo. Patrology, Vol. 4: The Golden Age of Latin Patristic Literature. Westminster: Christian Classics, Inc., 1992.

91. Gerber, Chad Tyler. The Spirit of Augustine's Early Theology: Contextualizing Augustine's Pneumatology. London: Routledge, 2016.

92. Turner, John. "The Chaldaean Oracles and the Metaphysics of the Sethian Platonizing Treatises." In Plato's Parmenides and its Heritage. Atlanta: SBL, 2010, vol. 2, pp. 213-32.

93. Victorinus, Marius. Marii Victorinii Ars grammatica, introduzione, testo critico e commento. Edited by Italo Mariotti. Florence: Felice Le Monnier, 1976.

94. Hof, Hans. Scintilla Animae: Eine Studie zu einem Grundbegriff in Meister Eckharts Philosophie mit besonderer Berücksichtigung des Verhältnisses der Eckhartschen Philosophie zur neuplatonischen und thomistischen Anschauung. Lund: C.W.K. Gleerup, 1952.

95. Dillon, John. "The Descent of the Soul in Middle Platonism and Gnostic Theory." In The Rediscovery of Gnosticism. Edited by Bentley Layton. Leiden: Brill, 1980, pp. 357-64.

96. De Leusse, Hubert. "Le problème de la préexistence des âmes chez Marius Victorinus." Recherches de science religieuse 29 (1939): 197-239.

97. Steinmann, Werner. Die Seelenmetaphysik des Marius Victorinus. Hamburg: Steinmann \& Steinman, 1990.

98. Erdt, Werner. Marius Victorinus Afer, der erste lateinische Pauluskommentator. Studien zu seinen Pauluskommentaren im Zusammenhang der Wiederentdeckung des Paulus in der abendländischen Theologie des 4. Jhs. Frankfurt: Peter Lang, 1980.

99. Cho, Dongsun. “Justification in Marius Victorinus' Pauline Commentaries: Sola Fide, Solo Christo, and Sola Gratia Dei." Journal for Baptist Theology E Ministry 11 (2014): 3-25.

100. Dillon, John. "Plutarch and Second Century Platonism." In Classical Mediterranean Spirituality: Egyptian, Greek, Roman. Edited by Arthur Hilary Armstrong. New York: Crossroad, 1986, pp. 214-29.

101. Dillon, John. "The Transcendence of God in Philo: Some Possible Sources." In The Golden Chain. Aldershot: Variorum, 1990, ch. IX.

102. Philo of Alexandria. Philo: Volume IX. Translated by F. H. Colson. Cambridge: Harvard University Press, 1941.

103. Burnyeat, Miles. "Platonism in the Bible: Numenius of Apamea on Exodus and Eternity." In Metaphysics, Soul, and Ethics in Ancient Thought: Themes From the Work of Richard Sorabji. Edited by Ricardo Salles. Oxford: Clarendon Press, 2005, pp. 143-69.

104. Van Nuffelen, Peter. Rethinking the Gods: Philosophical Readings of Religion in the Post-Hellenistic Period. Cambridge: Cambridge University Press, 2011.

(C) 2016 by the author; licensee MDPI, Basel, Switzerland. This article is an open access article distributed under the terms and conditions of the Creative Commons Attribution (CC-BY) license (http://creativecommons.org/licenses/by/4.0/). 